\title{
Cryptosporidium parvum in captive primates of Parque Municipal Danilo Galafassi, Paraná, Brazil
}

\section{Cryptosporidium parvum em primatas cativos do Parque Municipal Danilo Galafassi, Paraná, Brasil}

\author{
Alessandra Snak ${ }^{1 *}$; Luis Eduardo da Silveira Delgado ${ }^{2}$; Silvia Cristina Osaki ${ }^{3}$
}

\begin{abstract}
A wide variety of terrestrial and aquatic animal species have been identified as hosts of species and genotypes of Cryptosporidium spp., which are important pathogens, however, little is known about their distribution in wild populations. Recent studies associating parasitological findings and molecular techniques have provided a new insight into host specificity and its potential transmission to humans. The objective of this study was to investigate the presence of Cryptosporidium spp. in feces of Callithrix sp. and Ateles paniscus, identify the species, and evaluate their phylogenetic relationships with other representatives of the genus. Four samples of feces were collected from an enclosure where three Callithrix jacchus and one Callithrix penicillate live; in addition, five samples were collected from an enclosure of an Ateles paniscus from Parque Municipal Danilo Galafassi, located in the city of Cascavel-PR. These samples were sent to the UFPR Biotechnology Laboratory, where the modified Ziehl-Neelsen staining technique was performed on microscope slides with fecal smear. Positive samples were submitted to DNA purification, extraction, PCR, and sequencing of the nuclear SSU rRNA region. Phylogenetic analysis based on Maximum Parcimony and Bayesian Inference were performed. Fifty percent (2: 4) of the feces samples from the enclosure of the Callithrix spp. and $60 \%$ (3:5) of samples from the Ateles paniscus enclosure were positive for Cryptosporidium spp. The phylogenetic analysis showed that the parasite found in both species of primates was recovered nested with others genotypes of C. parvum, and the genotype found in Callithrix spp. has high similarity with that one founded in several domestic animals. This is the first report of C. parvum in A. paniscus. Because it is an important zoonosis which does not have treatment, preventive measures must be adopted to avoid the spread of the disease.
\end{abstract}

Key words: Wild animals. Cryptosporidiosis. PCR.

\section{Resumo}

Uma grande variedade de espécies animais terrestres e aquáticas tem sido identificada como hospedeiros de espécies e genótipos de Cryptosporidium spp., que são importantes agentes patogênicos, mas pouco se conhece sobre a sua distribuição nas populações silvestres. Estudos recentes associando achados parasitológicos e técnicas moleculares têm proporcionado uma nova visão em relação à especificidade do hospedeiro e seu potencial de transmissão para o homem. O objetivo desse estudo foi pesquisar a presença de Cryptosporidium spp. em fezes de Callithrix spp. e Ateles paniscus, identificar a espécie e avaliar o seu relacionamento filogenético com outros representantes do gênero. Foram coletadas quatro

\footnotetext{
${ }^{1}$ Discente de Doutorado, Universidade do Estado de Santa Catarina, UDESC, Lages, SC, Brasil. E-mail: alessandra.snak@ hotmail.com

2 Médico Veterinário, Prefeitura Municipal de Cascavel, Cascavel, PR, Brasil. E-mail: dadodelgado@gmail.com

3 Prof ${ }^{a}$, Universidade Federal do Paraná, UFPR, Palotina, PR, Brasil. E-mail: silvia_cristinao@yahoo.com.br

* Author for correspondence
} 
amostras de fezes de um recinto onde convivem três Callithrix jacchus e um Callithrix penicillata e cinco amostras de um recinto onde vive um Ateles paniscus do Parque Municipal Danilo Galafassi localizado na cidade de Cascavel-PR. As amostras foram enviadas ao Laboratório de Biotecnologia da UFPR onde foi realizada a técnica de coloração de Ziehl-Neelsen modificado em lâminas de esfregaço de fezes. As amostras positivas foram submetidas à purificação, extração de DNA, PCR, e sequenciamento da região nuclear SSU rRNA. Foram realizadas análises filogenéticas baseadas em Máxima Parcimônia e Inferência Bayesiana. Cinquenta por cento (2:4) das amostras de fezes do recinto dos Callithrix spp. e 60\% (3:5) das amostras do recinto do Ateles paniscus foram positivas para Cryptosporidium spp. As análises filogenéticas demonstraram que o parasito encontrado nos primatas agrupou com outros genótipos de C. parvum e que o genótipo encontrado em Callithrix spp. possui alta similaridade com os encontrados em vários animais domesticados. Esse é o primeiro relato de C. parvum em A. paniscus. Por se tratar de uma importante zoonose e não ter tratamento, medidas preventivas devem ser adotadas para evitar a disseminação da doença.

Palavras-chave: Animais silvestres. Criptosporidiose. PCR.

The occurrence and species of parasites in zoohoused animals may vary according to the handling of the animals and the conditions of the enclosures. Generally, these environments have green areas and refuges, in order to reduce animal stress; however, they hinder the access and complete hygiene and disinfection of the enclosures, facilitating the maintenance and propagation of parasites in these environments. Another important factor for maintenance of the main parasites in captive animals are synanthropic animals, such as rodents and wild birds, which have access to the enclosures and end up facilitating the spread of the parasites (LASPRILLA et al., 2009).

Protozoan of Phylum Apicomplexa, Cryptosporidium spp. parasites several species of animals and mainly causes gastrointestinal disorders, such as diarrhea. It is of greater importance in immunosuppressed individuals; in humans, it affects mainly the elderly, children and HIV carriers (RYAN; HIJJAWI, 2015).

There are about 27 species of Cryptosporidium spp. and 40 genotypes that parasitize humans and/or animals. Three, 19, one, two and two species infect birds, mammals, amphibians, reptiles and fish, respectively. Of these, 20 species can infect humans (RYAN; HIJJAWI, 2015).

Several studies report the presence of the parasite in wild animals, but rare are those that make the molecular characterization of the parasite in these species of animals.

The objective of this work was to investigate the presence of Cryptosporidium spp. and identify its species in feces of Callithrix spp. and Ateles paniscus captive in the Parque Municipal Danilo Galafassi, in Cascavel, Paraná, Brazil. phylogenetic relationships with other representatives of the genus.

Four fecal samples were collected from an enclosure, where there are three Callithrix jacchus and one Callithrix penicillata, and five fecal samples from an enclosure where an Ateles paniscus lives. Samples were packed in clean containers with a screw cap, identified and kept under refrigeration until processing.

Approximately two grams of feces were diluted in $15 \mathrm{~mL}$ of water and posteriorly passed through a sieve enveloped with a gauze into another container, to remove the solid particles. Thereafter, a small sample of the liquid was centrifuged for two minutes at 2,500rpm, discarding the supernatant. Slides were made using the sediment.

After drying the slide, the modified ZiehlNeelsen staining method was performed, described by Ortolani (2000). The slides were examined under a light microscope 1000 times magnified.

A pool of positive samples of each animal species was collected and subjected to purification, genomic DNA extraction, double polymerase chain reaction (nested-PCR) and DNA sequencing. 
The purification was performed through the discontinuous density gradient using $1 \mathrm{M}$ sucrose.

In order to perform the genomic DNA extraction, fifteen cycles of freezing and thawing were performed to break the oocyst wall (OSAKI et al., 2013), followed by the use of the commercial ChargeSwitch ${ }^{\circledR}$ gDNA Mini Tissue kit (Invitrogen). The double polymerase chain reaction (nested-PCR) was performed following the protocol described by Macarisin et al. (2010), using the primers XIAF/ XIAR (5'TTC TAG AGC TAA TAC ATG CG3', 5'CCC ATT TCC TTC GAA ACA GGA3') on the first step, and XIA1F/XIA2R (5'GGA AGG GTT GTA TTT ATT AGA TAA AG3', 5'AAG GAG TAA GGA ACAACC TCC A3') on the second step. However, Bovine Serum Albumin (BSA) was not used. The amplified products were visualized on $1.6 \%$ agarose gel by electrophoresis.

PCR products were sequenced in both directions using the Big Dye Terminator v3.1 Cycle Sequencing Kit (Applied Biosystems, Austin, Texas, USA) and the same primers of the second PCR step in a final volume of $10 \mu \mathrm{L}$, according to the following protocol: $3 \mathrm{~min}$ of initial denaturation at $96^{\circ} \mathrm{C}, 25$ cycles of $96^{\circ} \mathrm{C}$ denaturation for $10 \mathrm{~s}, 55^{\circ} \mathrm{C}$ annealing for $10 \mathrm{~s}$, and $60^{\circ} \mathrm{C}$ extension for $4 \mathrm{~min}$. Sequencing products were cleaned using isopropanol $75 \%$ and ethanol $60 \%$, and analyzed on a ABI-Prism 3500 Genetic Analyzer (Applied Biosystems) at ACTGene Análise Moleculares Ltda. (Alvorada, Rio Grande do Sul). The electropherograms were assembled and edited using the Geneious platform.

For the phylogenetic analyses the sampling includes 51 accessions of Cryptosporidium corresponding to 12 species and different genotypes of C. parvum, and the two new sequences generated in this study (MK079666- Callithrix spp., MK078103- A. paniscus). Eimeria tenella was chosen as outgroups based on XIAO et al. (1999). Multiple sequence alignment was performed using MUSCLE with default settings. Alignments were inspected and adjusted manually using Geneious.

Parsimony analysis were performed using PAUP/ v. $4 . a 164$ with Fitch parsimony as the optimality criterion. Heuristic searches were performed with 1000 random taxa-addition replicates, and TBR branch-swapping, and retaining up to 15 trees per replicate. The resulting trees were used as starting trees for a subsequent round of TBR swapping. Clade support was evaluated using non-parametric bootstrapping with 2000 replicates, simple taxonaddition, and TBR algorithm, saving 15 trees per replicate. Only bootstrap percentages $(\mathrm{BP})>85$ were considered as strong support.

Bayesian analysis were performed using MrBayes v.3.2.6. Nucleotide substitution model were selected using the Akaike information criterion (AIC) in MrModeltest v.2.3. Two runs using the Metropolis-coupled MCMC (Markov Chain Monte Carlo) algorithm, each with four random-initiated chains (one 'cold' and three 'heated'), involved 10 million generations and these were sampled every 1000 generations. The convergence of the runs was assessed by checking if the standard deviation of split frequencies reached a value below 0.01 . Trees generated before convergence were excluded as burnin and the effective sample size (ESS) of all parameters was checked to verify if the values were $>200$. The remaining trees were summarized into a majority-rule consensus tree including the posterior probabilities (PP) as branch support estimates. Only PP values $\geq 95$ were considered as a strong support. Parsimony and Bayesian analyses were performed in the CIPRES Science Gateway. The trees were edited using FigTree v.1.3.1.

The present study showed a high occurrence of Cryptosporidium spp. in the feces of the animals surveyed. Fifty percent (2/4) of the feces samples from the Callithrix spp. and 60\% (3/5) of the samples from the Ateles paniscus enclosure were positive for Cryptosporidium spp. The phylogenetic analyses recovered the parasites found in the primates nested among different genotypes of $C$. parvum with high support (1PP, 77BS) (Figure 1). Although the clade of $C$. parvum was largely unresolved, one the two accessions generated in this study (C_parvum Callithrix_sp) has a sequence identical to those of C. parvum found in water and soil samples from the city of Londrina-PR, in samples of Gallus gallus 
from the State of Paraná, and in samples of cattle, sheep, dogs, and deer from various parts of the world. Despite the low level of variation found in the SSU rRNA region, it may indicate that the pathogen found in our samples is more related to those found in these samples than the others we included in the analyses. The sequence of our second sample $\left(\mathrm{C}_{-}\right.$ parvum_Ateles_paniscus) was too short to allow us any interpretations.
Oocysts of Cryptosporidium spp. have been found in several species of primates worldwide, however, C. parvum is not the most common species parasitizing primates, although it has already been reported in several species, including Callithrix spp. (SRICHARERN et al., 2016; ZANZANI et al., 2016; LIU et al., 2015; DU et al., 2015; LUDWIG; MARQUES, 2011).

Figure 1. Bayesian 50\% consensus tree resulting from the SSU rRNA analyses of Cryptosporidium sp. Bayesian posterior probabilities (only values $>50 \%$ ) and parsimony bootstrap support values are reported above and below branches, respectively. The tip labels are composed by Cryptosporidium species_host_GenBank accession. The red color on the tips indicates the sequences generated in this study.

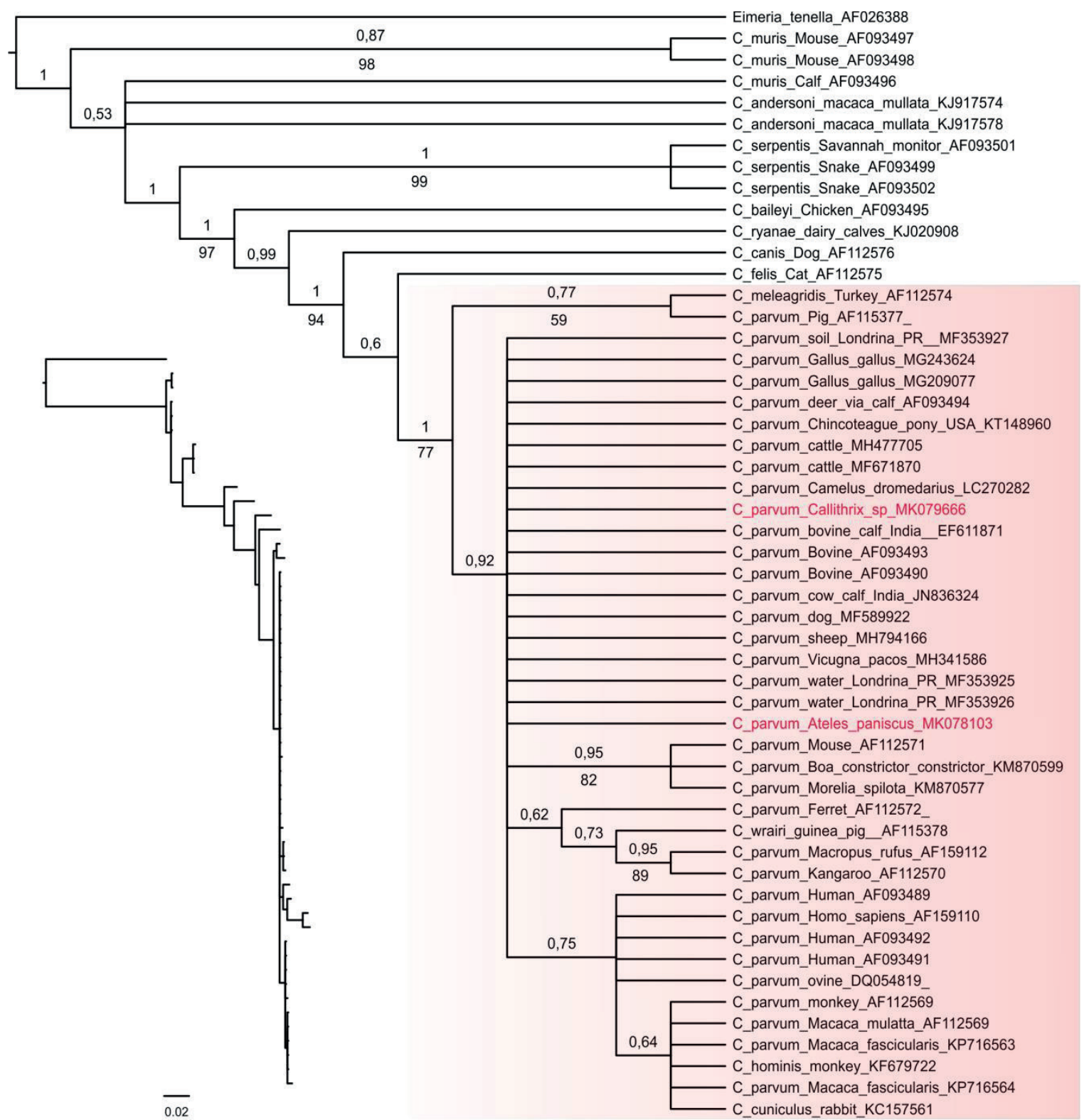


Other authors have reported the presence of oocysts of Cryptosporidium sp. in Ateles paniscus (VENTURINI et al., 2006) without demonstrating the species. This is the first work with molecular characterization of the parasite in red-faced black spider monkey; therefore, this is the first report of C. parvum in A. paniscus.

Although the main clinical sign of the protozoa is diarrhea, no stool sample analyzed in this study was diarrheal. Kalishman et al. (1996) reported that the species of the Callithrix genus are usually asymptomatic; thus, it is believed that in most cases, primates will only show clinical signs in the case of immunosuppression, as described by Hahn and Capuano (2010) who reported two cases of enterocolitis caused by $C$. parvum in immunosuppressed marmosets.

The source of infection of these zoo animals is still unknown, but animals are believed to have been contaminated through water or through contact with other contaminated animals, such as synanthropic animals, which may end up contaminating the food and the enclosure.

Cryptosporidium parvum is one of the most found species parasitizing various animals, such as cattle, dogs, cats, swine, wild mammals, aquatic mammals, and wild birds, and is considered the species with the highest zoonotic potential (RYAN; HIJJAWI, 2015), generating a major concern about the potential contamination of handlers and visitors who have contact with these animals.

For the reason that it is an important zoonosis of easy dissemination between the human and animal population, preventive measures must always be taken to avoid contamination of other animals and humans.

Oocysts of C. parvum were found in most of the feces of the investigated animals, demonstrating a high occurrence of the protozoa in the samples studied.

This is the first report of C. parvum in A. paniscus

\section{References}

DU, S. Z.; ZHAO, G. H.; SHAO, J. F.; FANG, Y. Q.; TIAN, G. R.; ZHANG, L. X.; WANG, R. J.; WANG, H. Y.; QI, M.; YU, S. K. Cryptosporidium spp.; Giardia intestinalis, and Enterocytozoon bieneusi in captive nonhuman primates in Qinling Mountains. Korean Journal of Parasitology, Seoul, v. 53, n. 4, p. 395-402, 2015.

HAHN, N. E.; CAPUANO, S. V. Successful treatment of cryptosporidiosis in 2 common marmosets (Callithrix jacchus) by using paromomycin. Journal of American Association for Laboratory Animal Science, Memphis, v. 49, n. 6, p. 873-875, 2010.

KALISHMAN, J.; PAUL-MURPHY, J.; SCHEFFLER, J.; THOMSON, J. A. Survey of Cryptosporidium and Giardia spp. in a captive population of common marmosets. Laboratory Animal Science, Memphis, v. 46, n. 1, p. 116-119, 1996.

LASPRILLA, M.; OCAMPO, M.; LÓPEZ, G. Identificación de huevos de nemátodos en carnívoros y primates ubicados en el Zoológico Santa Fe de Medellín, mediante método covprológico directo y de flotación. Revista Spei Domus, Bucaramanga, v. 5, n. 10, p. 30-36, 2009.

LIU, X.; XIE, N.; LI, W.; ZHOU, Z.; ZHONG, Z.; SHEN, L.; YU, X.; HU, Y.; CHEN, W.; PENG, G. Emergence of Cryptosporidium hominis monkey genotype II and novel subtype family $\mathrm{lk}$ in the squirrel monkey (Saimiri sciureus) in China. PLos One, San Franscisco, v. 10, n. 10, p. 1-10, 2015.

LUDWIG, R.; MARQUES, S. M. T. Occurrence of Cryptosporidium spp. oocysts in mammals at a zoo in southern Brazil. Revista Ibero-Latinoamecana Parasitologica, Santiago, v. 70, n. 1, p. 122-128, 2011.

MACARISIN, D.; SANTIN, M.; BAUCHAN, G.; FAYER, R. Infectivity of Cryptosporidium parvum oocysts after storage of experimentally contaminated apples. Journal of Food Protection, Des Moines, v. 73, n. 1, p. 1824-1829, 2010.

ORTOLANI, E. L. Standardization of the modified ZiehlNeelsen technique to stain oocysts of Cryptosporidium sp. Revista Brasileira de Parasitologia Veterinária, Jaboticabal, v. 9, n. 1, p. 29-31, 2000.

OSAKI, S. C.; SOCCOL, V. T.; COSTA, A. O.; OLIVEIRA-SILVA, M. B.; PEREIRA, J. P.; PROCÓPIO, A. E. Polymerase chain reaction and nested-PCR approaches for detecting Cryptosporidium in water catchments of water treatment plants in Curitiba, State of Paraná, Brazil. Revista da Sociedade Brasileira de Medicina Tropical, Brasília, v. 46, n. 3, p. 270-276, 2013. 
RYAN, U.; HIJJAWI, N. New developments in Cryptosporidium research. International Journal for Parasitology, Oxford, v. 45, n. 6, p. 367-373, 2015.

SRICHARERN, W.; INPANKAEW, $T$. KEAWMONGKOL, S.; SUPANAM, J.; STICH, R. W.; JITTAPALAPONG, S. Molecular detection and prevalence of Giardia duodenalis and Cryptosporidium spp. Among long-tailed macaques (Macaca fascicularis) in Thailand. Infection, Genetics and Evolution, Amsterdam, v. 40, p. 310-314, 2016.

VENTURINI, L.; BACIGALUPE, D.; BASSO, W.; UNZAGA, J. M.; VENTURINI, M. C.; MORÉ, G. Cryptosporidium parvum in domestic animals and in monkeys from a zoo. Parasitologia Latioamericana, Santiago, v. 61, n. 1-2, p. 90-93, 2006.

XIAO, L.; MORGAN, U. M.; LIMOR JLIMOR, J.; ESCALANTE, A.; ARROWOOD, M.; SHULAW, W.; THOMPSON, R. C.; FAYER, R.; LAL, A. A. Genetic diversity within Cryptosporidium parvum and related Cryptosporidium species. Applied and Environmental Microbiology, Washington, v. 65, n- 8, p. 3386-3391, 1999.

ZANZANI, S. A.; GAZZONIS, A. L.; PPIS, S.; MANFREDI, M. T. Study of the gastrointestinal parasitic fauna of captive non-human primates (Macaca fascicularis). Parasitology Research, Berlin, v. 115, n. 1, p. 307-312, 2016. 